\title{
A Comparison Study of Bank Efficiency in Indonesia Before and After Crisis in 2008 Based on Data Envelopment Analysis
}

\author{
Cut Nabila Saraziva ${ }^{1, *}$ Dony Abdul Chalid ${ }^{2}$
}

\author{
${ }^{1}$ Universitas Indonesia \\ ${ }^{2}$ Universitas Indonesia \\ *Corresponding author. Email: saraziva96@gmail.com
}

\begin{abstract}
During financial crisis, the profitability of businesses tend to decline. Therefore, managements aim to minimize inefficiencies in running their businesses. Using 35 banks in Indonesia, we analyze the crisis effect on bank's efficiency before and after crisis in 2008. Methods used in this study are data envelopment analysis (DEA), Wilcoxon test, and analysis of variance which applied to accounting data spanning from 2006 to 2019. The result shows that most banks (43\%-69\%) are not efficient yet from 2006 to 2019. The majority of banks in Indonesia have not yet performed their function as an intermediary wherein they are not efficient enough to utilize their inputs to produce a certain level of output. This study shows significant differences between bank efficiency before and after crisis based on Wilcoxon test. This indicates that regulations and business models after crisis in 2008 have a significant impact on bank efficiency in Indonesia. Some variables (total assets, operating expenses, total revenues, and net income) show an increasing growth even after the crisis. On the other hand, this study shows there is no significant differences between bank efficiency based on BUKU (Bank Umum berdasarkan Kegiatan Usaha) or bank based on business activities based using analysis of variance. On average, large banks are more efficient even during the financial crisis. This study also shows there is no significant differences between bank efficiency based on capital adequacy ratio buffer using analysis of variances. However, this study shows that there is significant differences between bank efficiency based share ownership. Bank with majority of local ownership is found to be more efficient. This study shows that the regulatory framework seems to play a crucial role in the banks' efficiency configuration. Regulators can design the policy to be more compatible and adaptable related with the issues happened. Hence, the policy needs to promote productivity, capitalization, and development whereas at the same time controlling its efficiency.
\end{abstract}

Keywords: Bank, Efficiency, Indonesia, Crisis, Data Envelopment Analysis, DEA.

\section{INTRODUCTION}

As a company in the service sector, public trust in a bank is considered essential in operating its activities. Bank performance is one of the determinants in gaining public trust. Until this moment, a bank's efficiency is still relevant in evaluating bank performance. Bank contributed to economic activities, especially in developing countries, in which banks are the main channel for capital flows. Hence, a key issue raised about bank efficiency to reinforce the effectiveness and also the resilience of the financial set-up (Otero et al., 2019). Unstable events such as globalization, innovation, crisis, etc. could affect the bank's behavior and authorities behavior. According to Colesnic (2019), it is found that small banks are more efficient than large banks. It is said that size of bank has less negative influence on efficiency. Differently, banks with large size are more adaptable throughout the crisis. The studies related to bank efficiency in Indonesia have been conducted, yet most studies focused only on one to three banks. This study provides a broader view in analyzing the crisis effect on a bank's efficiency levels before and after the crisis in 2008 using 35 banks in Indonesia.

In the first stage, to estimate the bank's efficiency level from 2008 to 2019, data envelopment analysis (DEA) is applied. Using Banker Charnes Cooper (BCC) model, intermediation approach and orientation output, total deposits, total assets, and operating expenses are selected as input variables whereas total loans, total revenues, and net income as output variables. In the second stage, Wilcoxon test is introduced, in order to compare bank's efficiency score before and after the crisis in 2008. In the third stage analysis of variance is applied to compare bank's efficiency score based on BUKU (Bank Umum Kegiatan Usaha) or bank based on 
business activities. In the fourth stage, analysis of variance is applied to compare bank's efficiency score based on capital adequacy ratio buffer. In the last stage, Wilcoxon test is applied to compare bank's efficiency score based on majority shareholder ownership.

The rest of the paper is structured as follows: The second section presents the literature review related to this research. The third section describes the research methodology. The corresponding data and results are presented in the fourth section, and then the final section offers the conclusion of the research.

\section{LITERATURE REVIEW}

\subsection{Efficiency}

Bank's efficiency is still used to evaluate bank performance. When someone talks about the efficiency of a firm, it could be technical efficiency or allocative efficiency. Technical efficiency is defined as creating as much outputs as possible from the existing inputs (Colesnic et al., 2019). Meanwhile, allocative efficiency means capability to maximize input to produce output at a certain level (Farrel, 2011). To estimate efficiency, we can use ratio approach, regression approach, and frontier approach (Farrel, 2011). Among the frontier approach, the approach that used as often as possible to estimate bank efficiency is data envelopment analysis (DEA) (Hadad et al., 2003). To distinguish between "management efficiency" and "program efficiency", it is done via approach called as Data Envelopment Analysis, in which one to begin with gets boundaries or envelopes of information (Christopoulos et al., 2019).

\subsection{Data Envelopment Analysis}

The term decision-making unit (DMU) is meant to stress and orientation toward public firm, private firm, or non profit firm (Charnes et al., 1981). In short, DMU is an object that will be used in this study. With DEA, boundaries or envelopes are obtained to estimate the relative efficiency of DMU's. If a DMU can add output without adding any input or diminishing any output, this DMU is not efficient (Charnes et al., 1981). Basically, DEA program will correlate the input and output variables of a firm with the input and output variables from a group of similar firms. After the comparison, the efficiency score of DMU will be obtained in a group of DMUs that form a frontier line. DMU is called efficient if DMU is located on the frontier line, where DMU is relatively efficient when compared to the group of DMU. In analyzing efficiency, there are two models that are usually used, Charnes Cooper and Rhodes (CCR) model and Banker Charnes and Cooper (BCC) model. CCR model allows constant return to scale where the relationship is linear, an input will add an output. Meanwhile, BCC model allows variable return to scale where the relationship is nonlinear, an input can add less or more an output. CCR model is more appropriate for analyzing manufacturing companies' performance, while BCC model is more appropriate for service companies.

\subsection{Research regarding Efficiency}

Christopoulos (2019) evaluated bank efficiency on Eurozone country after the crisis. This study relies on DEA to measure efficiency. Based on the intermediation approach chosen in this study, the input variables are operational costs, total assets, and a number of employees, while the output variable is net income after provision. Besides, this study also measures the influence of financial and macroeconomic factors such as Capital on Risk-Weighted Assets, Tangible Common Equity to Risk, GDP, and others on efficiency. Based on the efficiency measure, it was found that Portugal was the most efficient country, followed by Italy, Spain, Greece, and finally Ireland. Besides, in this study it was found that the increase in Core Capital to Risk-Weighted Assets or Capital Adequacy Ratio and Non-Performing Assets to Total Assets had a significant effect on reducing bank efficiency scores. Meanwhile, the increase in RiskWeighted Asset to Total Asset and Net Income Margin had a significant effect on the increase in bank efficiency scores.

According to Colesnic (2019), ), it is found that small banks are more efficient than large banks. It is said that size of bank has less negative influence on efficiency. Differently, banks with large size are more adaptable throughout the crisis. Moreover, large banks with higher fixed assets are correlated to a large number of nonperforming loan disbursements which justifies the rejection of the positive relationship between bank size and bank efficiency (Charnes et al., 1981).

On the other hand, Otero (2019) evaluated what factors that drive bank efficiency in Middle Eastern and Northern African (MENA). Based on the intermediation approach chosen in this study, input variables are total employees, total fixed assets, and total deposits, while output variables are total loans and other important accounts in the financial position report. In this study it was found that at individual level, the scale of the bank and the level of capital had a positive impact on bank efficiency in MENA. Meanwhile, at country level, inflation and GDP are positively related to total costs.

\section{METHODOLOGY}

\subsection{Research Design}

The research design used in this study is a nonexperimental approach with quantitative descriptive methods. A non-experimental research design is a study that collects several types of numerical data to answer specific research questions (Colesnic et al., 2019). 
Meanwhile, casual research tries to find the effect a variable has on other variables or why certain results are obtained (Christensen, 1994). The concept of quality is based on the logic of testing hypotheses, which will ultimately lead to conclusions. This research design is used to describe the comparison of bank efficiency in Indonesia before and after crisis in 2008, bank efficiency score based on BUKU, bank's efficiency score based on capital adequacy ratio buffer, and bank's efficiency score based on majority shareholder ownership.

\subsection{Data Collection}

Data used in this study is based on statement of financial position and statement of profit or loss spanning from 2006 to 2019. Total deposits, total assets, and operating expenses are selected as input variables whereas total loans, total revenues, and net income are selected as output variables based on intermediation approach, which considers banks as intermediaries between savers and investors so that they can generate profits. In this study, the intermediation approach is used in this study since it is more reasonable in appraising financial institutions and their profitability.

\subsection{Research Method}

This study uses DEA where the efficiency score measured by BCC model with an intermediation approach and output orientation, so that a comparative analysis of the efficiency can be conducted. BCC model is written down below:

$$
\min _{i}=\Theta_{0}
$$

$$
\begin{gathered}
\text { Subject to } \sum_{j=1}^{n} \lambda_{j} y_{r j} \geq y_{r 0,} r=1,2, \ldots, s \\
\Theta_{0} x_{i 0}-\sum_{j=1}^{n} \lambda_{j} x_{r j} \geq 0 i=1,2, \ldots, m \\
\sum_{j=1}^{n} \lambda_{j}=1 \\
\lambda_{j} \geq 0, j=1,2, \ldots, n
\end{gathered}
$$

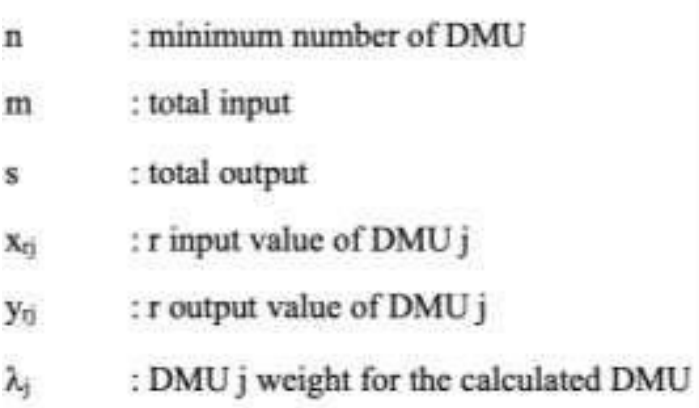

In DEA method, decision-making unit (DMU) is meant to stress and orientation toward public firm, private firm, or non profit firm (Cooper \& Schindler, 2017). In short, DMU is an object that will be used in this study. DMUs in this study are Bank in Indonesia, both public banks and private banks, which published financial reports for the period 2006 to 2019. Total DMUs need to be ensured, so it meets the degree of freedom which is determined by this following equation:

$$
\begin{array}{ll}
\mathrm{n} \geq \mathrm{max} & \{\mathrm{m} \times \mathrm{s}, 3(\mathrm{~m}+\mathrm{s})\} \\
\mathrm{n} & : \text { minimum number of DMU } \\
\mathrm{m} & : \text { total input } \\
\mathrm{s} & : \text { total output }
\end{array}
$$

Based on that equation, here is the calculation:

$\mathrm{n} \geq \max \{3 \times 3,3(3+3)\}$

$\mathrm{n} \geq \max \{9,18\}$

Based on this calculation, the minimum total DMUs in this study is at least 18 DMUs. This study uses 35 banks in Indonesia as object of the research, so that total DMUs exceed the minimum total DMUs, which means it already meets the degree of freedom. 


\section{RESULT AND DISCUSSION}

Table 2 (see appendix) shows descriptive statistics of the bank efficiency from 2006 to 2019 based on data envelopment analysis (DEA). There are 35 banks that meet the criteria to become a decision-making unit (DMU) in this study. DMUs that are said to be efficient if the score is 1 and DMUs that are not said to be efficient if the score is below 1. It can be seen from table 1 (see appendix), DMUs that are inefficient (43\%$69 \%$ ) are much larger than DMUs that are efficient $(31 \%-57 \%)$. This indicates that the majority of banks in Indonesia are not efficient enough. Majority of banks in Indonesia have not yet performed their function as an intermediary wherein they are not efficient enough to utilize their inputs to produce a certain level of output. The number of efficient DMUs has fluctuated annually. The average efficiency score ranged from 0.877 to 0.981 from 2006 to 2019 where the scores tend to decline.

Based on Wilcoxon test in table 3 (see appendix), it is found that there is significant differences between bank efficiency in Indonesia before and after crisis in 2008. This indicates that regulations and business models after crisis in 2008 have a significant impact on bank efficiency in Indonesia. Based on table 2 (see appendix), total loans experienced the sharpest decline in growth in which the growth before crisis in 2008 is $28.48 \%$ and the growth after crisis in 2008 is $26,20 \%$. This shows that business conditions that may have been shaken after crisis in 2008 resulted in lack of loans for productive purposes. Besides, people have put aside their consumptive behavior after crisis in 2008, which resulted in a lack of loans for consumptive needs. This is followed by a decline in the growth of total deposits in which the growth before crisis in 2008 is $18.25 \%$ and the growth after crisis in 2008 is $17.26 \%$. This shows that people tend to prioritize saving their funds in the form of liquid cash instead of saving in bank. Meanwhile, net profit experienced the sharpest increase in which the growth before the crisis in 2008 is $19.25 \%$ and the growth after the crisis in 2008 is $46.64 \%$. This growth is followed by an increase in the growth of total revenues and a decrease in the growth operating expenses. This shows that bank's ability to generate income and optimize operating expenses has improved after crisis in 2008, which is reflected in an increase in the growth of net income.
Using analysis of variance in table 4 (see appendix), it is found that there is no significant differences between bank efficiency between BUKU (Bank Umum Kegiatan Usaha) or bank based on business activities. BUKU 2 is group of banks with capital of IDR 1 trillion to IDR 5 trillion, BUKU 3 is group of banks with capital of IDR 5 trillion to IDR 30 trillion, and BUKU 4 is group of banks with capital of more than IDR 30 trillion. $51.90 \%$ banks are efficient in group BUKU 2, 36.81\% banks are efficient in group BUKU 3, and $63.27 \%$ bank are efficient in group BUKU 4. Meanwhile, during financial crisis $66.67 \%$ banks are efficient in group BUKU 2, $38.46 \%$ banks are efficient in group BUKU 3, and

$71.43 \%$ bank are efficient in group BUKU 4. This finding is in alignment with other studies (Colesnic et al., 2019), who shows banks with large size are more adaptable throughout the crisis. Using analysis of variance in table 5 (see appendix), it is found that there is no significant differences between bank efficiency based on Capital Adequacy Ratio buffer. On the other side, it is found that bank with higher capital adequacy ratio buffer is followed with lower efficiency score. This suggests that banks with low efficiency score is followed with a better ability in providing funds to overcome possible losses. Using analysis of variances in table 6 (see appendix), it is found that there is significant differences between bank efficiency based on majority shareholders. Bank with majority shareholders ownership by local investors is more efficient. This suggests that bank with majority shareholders ownership by local investors is likely to have a larger capitalization and dominate the market share of banks in Indonesia. 
Table 1 Bank Efficiency Based on Data Envelopment Analysis
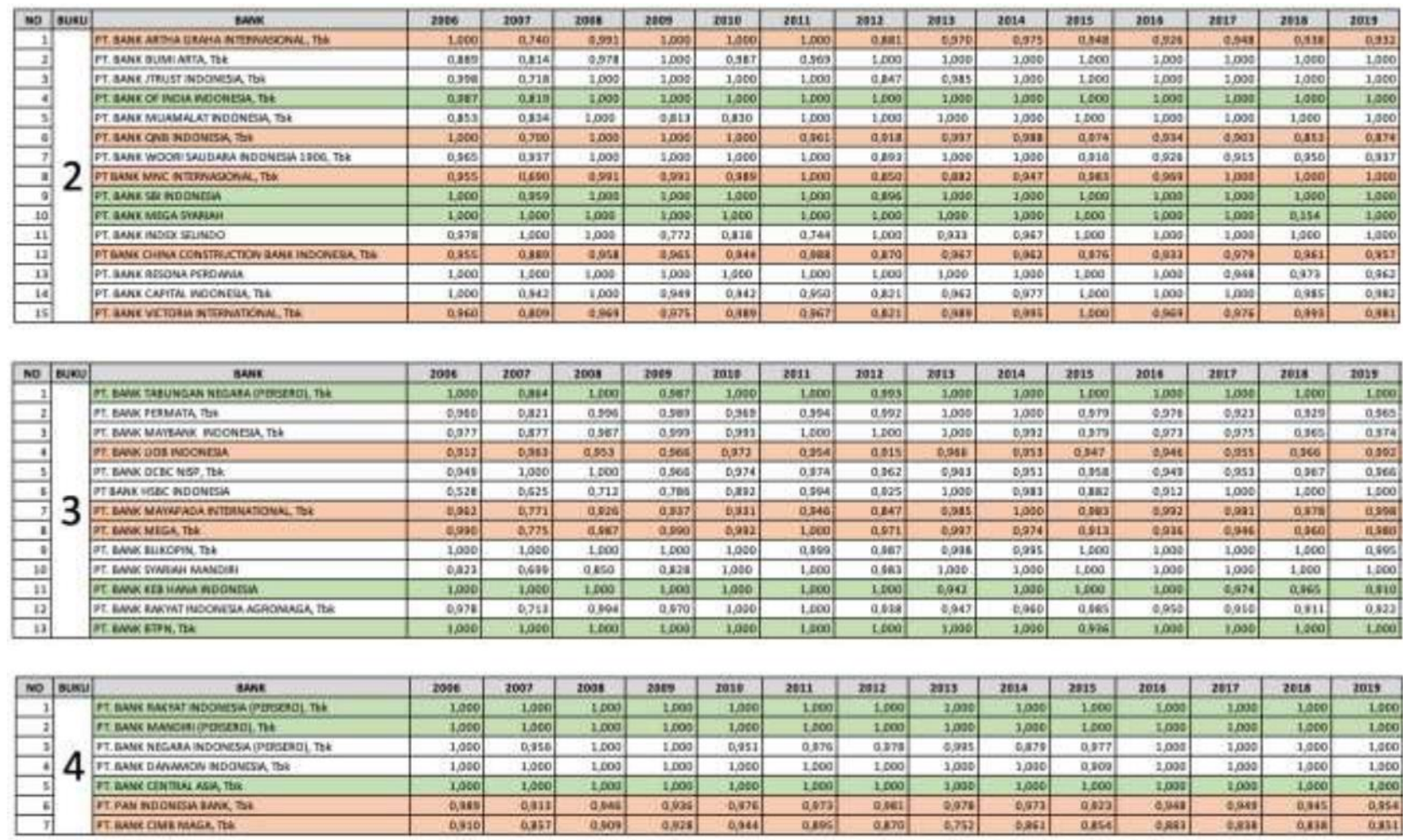

Table 2 Summary of Data Envelopment Analysis Results

\begin{tabular}{|l|r|r|r|r|r|r|r|r|r|r|r|r|r|r|}
\hline & $\mathbf{2 0 0 6}$ & $\mathbf{2 0 0 7}$ & $\mathbf{2 0 0 8}$ & $\mathbf{2 0 0 9}$ & $\mathbf{2 0 1 0}$ & $\mathbf{2 0 1 1}$ & $\mathbf{2 0 1 2}$ & $\mathbf{2 0 1 3}$ & $\mathbf{2 0 1 4}$ & $\mathbf{2 0 1 5}$ & $\mathbf{2 0 1 6}$ & $\mathbf{2 0 1 7}$ & $\mathbf{2 0 1 8}$ & $\mathbf{2 0 1 9}$ \\
\hline $\begin{array}{l}\text { Total } \\
\text { Efficient } \\
\text { DMUs }\end{array}$ & 15 & 11 & 20 & 17 & 18 & 20 & 13 & 17 & 18 & 17 & 19 & 19 & 17 & 17 \\
\hline $\begin{array}{l}\text { Total } \\
\text { Inefficient } \\
\text { DMUs }\end{array}$ & 20 & 24 & 15 & 18 & 17 & 15 & 22 & 18 & 17 & 18 & 16 & 16 & 18 & 18 \\
\hline Total DMU & 35 & 35 & 35 & 35 & 35 & 35 & 35 & 35 & 35 & 35 & 35 & 35 & 35 & 35 \\
\hline $\begin{array}{l}\text { \% DMU } \\
\text { Efficient }\end{array}$ & $43 \%$ & $31 \%$ & $57 \%$ & $49 \%$ & $51 \%$ & $57 \%$ & $37 \%$ & $49 \%$ & $51 \%$ & $49 \%$ & $54 \%$ & $54 \%$ & $49 \%$ & $49 \%$ \\
\hline $\begin{array}{l}\text { \% DMU } \\
\text { Inefficient }\end{array}$ & $57 \%$ & $69 \%$ & $43 \%$ & $51 \%$ & $49 \%$ & $43 \%$ & $63 \%$ & $51 \%$ & $49 \%$ & $51 \%$ & $46 \%$ & $46 \%$ & $51 \%$ & $51 \%$ \\
\hline $\begin{array}{l}\text { Mean of } \\
\text { Efficient } \\
\text { Score }\end{array}$ & 0.958 & 0.877 & 0.976 & 0.964 & 0.974 & 0.980 & 0.947 & 0.977 & 0.981 & 0.972 & 0.975 & 0.974 & 0.949 & 0.975 \\
\hline $\begin{array}{l}\text { Minimum } \\
\text { Efficient } \\
\text { Score }\end{array}$ & 0.528 & 0.625 & 0.712 & 0.772 & 0.818 & 0.744 & 0.821 & 0.752 & 0.861 & 0.854 & 0.883 & 0.838 & 0.154 & 0.851 \\
\hline $\begin{array}{l}\text { Maximum } \\
\text { Efficient } \\
\text { Score }\end{array}$ & 1.000 & 1.000 & 1.000 & 1.000 & 1.000 & 1.000 & 1.000 & 1.000 & 1.000 & 1.000 & 1.000 & 1.000 & 1.000 & 1.000 \\
\hline
\end{tabular}

Table 3 Wilcoxon Test: Efficiency Score Based on year 2008 and 2009

\begin{tabular}{|l|r|}
\hline$Z$ & $-3,600$ \\
\hline Asmp. Sig. (2-tailed) & .000 \\
\hline
\end{tabular}


Table 4 Analysis of Variances: Efficiency Score Based on BUKU

\begin{tabular}{|l|r|r|r|r|r|}
\hline & Sum of Squares & \multicolumn{1}{c|}{ df } & Mean Square & F & Sig. \\
\hline Between group & .001 & 2 & .000 & .331 & .721 \\
\hline Within Groups & .037 & 32 & .001 & & \\
\hline Total & .037 & 34 & & & \\
\hline
\end{tabular}

Table 5 Analysis of Variances: Efficiency Score Based on Capital Adequacy Ratio Buffer

\begin{tabular}{|l|r|r|r|r|r|}
\hline & Sum of Squares & \multicolumn{1}{c|}{ df } & Mean Square & F & Sig. \\
\hline Between group & .014 & 2 & .007 & .211 & .811 \\
\hline Within Groups & 1.064 & 32 & .033 & & \\
\hline Total & 1.078 & 34 & & & \\
\hline
\end{tabular}

Table 6 Wilcoxon Test: Efficiency Score Based on Majority Shareholder Ownership

\begin{tabular}{|l|r|}
\hline$Z$ & -2.897 \\
\hline Asmp. Sig. (2-tailed) & .004 \\
\hline
\end{tabular}




\section{CONCLUSION}

This study analyzes the comparison of bank efficiency in Indonesia before and after crisis in 2008 and then the characteristics of banks based on efficiency score. This study uses data envelopment analysis (DEA) in which total deposits, total assets, and operating expenses are selected as input variables whereas total loans, total revenues, and net income are selected as output variables according to the intermediation approach. Based on DEA, the majority of banks (43\%-69\%) in Indonesia are not efficient enough from 2006 to 2019. The majority of banks in Indonesia have not yet performed their function as an intermediary wherein they are not efficient enough to utilize their inputs to produce a certain level of output. It is found that there is significant differences between bank efficiency in Indonesia before and after crisis in 2008 based on Wilcoxon test. This indicates that regulations and business models after crisis in 2008 have a significant impact on bank efficiency in Indonesia. Some variables (total assets, operating expenses, total revenues, and net income) show an increasing growth even after the crisis. Using analysis of variances, it is found that there is no significant differences between bank efficiency based on BUKU (Bank Umum Kegiatan Usaha) or bank based on business activities. On average, large banks are more efficient even during the financial crisis. Using analysis of variances, It is also found that there is no significant differences between bank efficiency based on Capital Adequacy Ratio buffer. Bank with higher capital adequacy ratio buffer is followed with lower efficiency score. This suggests that banks with low efficiency score is followed with a better ability in providing funds to overcome possible losses. Meanwhile using Wilcoxon test, it is found that there is significant differences between bank efficiency based on majority shareholder ownership. Bank with majority shareholders ownership by local investors is likely to have a larger capitalization and dominate the market share of banks in Indonesia. This study shows that the regulatory framework play a crucial role in the banks' efficiency configuration. Regulators can design the policy to be more compatible and adaptable related with the issues happened. Regulators should adopt policies that can promote bank performance but at the same time controlling its efficiency. Hence, the policy needs to promote productivity, capitalization, and development whereas at the same time controlling its efficiency.
Further research could aim to use regression analysis in order to draw insight about the relationship between efficiency with size of bank, capital adequacy ratio buffer, and majority shareholder ownership.

\section{AUTHORS' CONTRIBUTIONS}

Authors contributed equally.

\section{ACKNOWLEDGMENTS}

We would like to thank the reviewers for their helpful comments. All possible remaining errors are our own.

\section{REFERENCES}

Chames, A., Cooper, W. W., \& Rhodes, E. (1981). Evaluating Program and Managerial Efficiency: An Application of Data Envelopment Analysis to Program Follow Through. Management Science, 27(6), 668697. https://doi.org/10.1287/mnsc.27.6.668

Christensen, L. B. (1994). Experimental methodology (6th ed.). Experimental Methodology (6th Ed.).

Christopoulos, A. G., Dokas, LG, Katsimardou, S., \& Spyromitros, E. (2019). Research in International Business and Finance Assessing banking sectors e ffi ciency of financially troubled Eurozone countries. October.

Colesnie, O., Kounetas, K., \& Michael, P. (2019). Estimating risk efficiency in Middle East banks before and after the crisis: A metafrontier framework. Global Finance Journal, June. https://doi.org/10.1016/j.gfj.2019.100484

Cooper, D., \& Schindler, P. (2017). Business Research Methods. Social Research.

Farrel, M. J. (2011). The Measurement of Productive Efficiency. Journal of the Royal Statistical Society Series A (General), 120(3), 259290.

Hadad, M. D., Santoso, W., Ilyas, D., \& Mardanugraha, E. (2003). Analisis Efisiensi Industri Perbankan Indonesia: Penggunaan Metode Non-Parametrik Data Envelopment Analysis (DEA). Bank Indonesia Research Paper.

Otero, L., Razia, A., Martorell, O., \& Mulet-forteza, C. (2019). What determines efficiency in MENA banks? Journal of Business, June. 